\title{
Susam Bitkisi (Sesamum indicum)'nin Farklı Dokularında Susam Fillodi Hastalığının Araştırılması
}

\author{
Ömer ERBİL ${ }^{1}$, Nüket ÖNELGE ${ }^{1}$, Orhan BOZAN ${ }^{1 *}$
}

\section{öz}

Susam yüksek kaliteli yağ ve yağ içeriği ile dünyanın başta gelen yağ bitkilerinden birisidir. Çukurova Bölgesi, Manisa ve Antalya'dan sonra susam tarımın en çok yapıldığı bölgedir. Çukurova Bölgesinde ikinci ürün olarak ekilen susamın en önemli sorunlarından bir tanesi susam fillodi hastalığıdır. Susam fillodi hastalığı bölgede birçok ilçede önemli verim kayıplarına neden olmaktadır. Bu çalışmada Adana ve Mersin ilçelerinde belirlenen susam tarlalarda susam fillodi hastalığı olduğu saptanan susam bitkilerinden alınan farklı dokularda hastalığın varlığ araştırılmıştır. Olgun yeşil çiçek, küçük yeşil çiçek, küçük yapraklar, cadı süpürgesi oluşumu, yaprak sapı, sürgün kabuğu, kapsül içinde çimlenmiş tohum, çimlenmiş tohum kapsülleri, kapsül içinde çimlenmemiş tohum ve çimlenmemiş tohum kapsülleri gibi farklı bitki aksamlarıyla çalışma yapılmıştır. Moleküler çalışmalar sonunda içinde susam tohumlarının da bulunduğu 10 farklı susam bitki dokularının tamamında susam fillodi hastalığı tespit edilmiştir.

Anahtar Kelimeler: Susam, Susam fillodi, PCR, Farklı doku parçaları

\section{ABSTRACT}

\section{Investigation of Sesame Phyllody Disease in Different Tissues of Sesame Plant (Sesamum indicum)}

\begin{abstract}
Sesame is one of the world's leading oil crops with its high quality oil and oil content. Çukurova Region is the region where sesame cultivation is done the most after Manisa and Antalya. One of the most important problems of sesame planted as a second crop in Çukurova Region is sesame phyllody disease. Sesame phyllody disease causes significant yield losses in many districts of the region. In this study, the presence of the disease was investigated in different tissues taken from sesame plants found to have sesame phyllody disease in the sesame fields determined in Adana and Mersin districts. The study was carried out with different plant parts such as mature green flower, small green flower, branches with short internodes, small leaf, leaf petiole, shoot bark, germinated seed, germinated seed capsul, ungerminated seed and germinated seed capsul. At the end of molecular studies, sesame phyllodes disease was detected in all 10 different sesame plant tissues, including sesame seeds.
\end{abstract}

Keywords: Sesame, Sesame phyllody, PCR, Different pieces of tissue

ORCID ID (Yazar sirasına göre)

0000-000-6466-7803, 0000-0002-5018-0850, 0000-0002-3274-5459

\footnotetext{
Yayın Kuruluna Geliş Tarihi: 17.06.2021

Kabul Tarihi: 23.06.2021

${ }^{1}$ Çukurova Üniversitesi, Ziraat Fakültesi, Bitki Koruma Bölümü, Sarıçam, Adana

*E-posta: gborhan@cu.edu.tr
} 


\section{Susam Bitkisi (Sesamum indicum)'nin Farklı Dokularında Susam Fillodi Hastalığının Araştırılması}

\section{Giriş}

Dünyada ve ülkemizde önemli bir yeri olan yağlı bitkiler içerdikleri yağ, mineral maddeler, karbonhidrat, protein ve vitaminler ile insan beslemesinde faydalanılırken, küspesi hayvan beslemesinde kullanılmasından dolayı önemli bir yere sahiptirler. Ayrıca sanayi sektöründe önemli bir hammadde kaynağı olarak da kullanılırlar. $\mathrm{Bu}$ yağlı bitkilerden susam (Sesamum indicum L.) dünyada kültürü yapılan en eski ve en önemli yağ bitkilerinden biridir (Arslan ve ark., 2014).

Susam Hindistan, Sudan ve Myanmar başta olmak üzere, dünyanın tropik ve suptropik iklim kuşaklarına sahip birçok yöresinde kültürü yapılan tek yıllık bir yağ bitkisidir. Dünya susam ekim alanı 9.983.165 ha olup, en fazla ekiliş alanına sahip ülkeler 1.800 .000 ha ile Hindistan ve 1.478.158 ha ile Myanmar'dır. Fakat üretim miktarı olarak Çin 524.156 ha'lık alandan 734.160 ton ve $119 \mathrm{~kg} / \mathrm{da}$ 'lık verim ile dünyada ilk sırada yer almaktadır. Ülkemizde ise bu oran 28.031 ha alanda 18.410 ton'dur (FAO, 2018).

Ülkemizde susam tarımı son yıllarda azalma göstermektedir, bunun sebebi olarak; çiftçilerin daha az işçilik gerektiren ürünler ekmesi, kuru şartlarda nadas alanlarında üretim yapılırken sulu tarıma geçildiğinde farklı bitkilere geçilmesi, ekim nöbetine susamın dahil edilmemesi, yüksek verimli sertifikalı tohumların kullanılmaması, kapsül çatlama problemi olan yerel tohumların kullanılması, üretimin genelde küçük aile işletmeciliği şeklinde olması, hasat sırasındaki verim kayıpları ve işçilik maliyetinin yüksek olması, makinalı hasada uygun tohumların bulunmaması gibi etkenler bildirilmiştir (Arslan ve ark. 2014).

Hasat ve yetiştiricilik problemlerinin dişında susamdaki hastalık ve zararlılarda verimde büyük kayıplara neden olmaktadır. Hastal1klardan en önemlisinin susam fillodi hastalığı olduğu bilinmektedir. Hastalığın görsel olarak bitkide oluşturduğu simptomlar; tohumların kapsül içinde çimlenmesi ve bundan dolayı hastalıklı bitkilerden sağlıklı tohum üretilememesi, bitkilerin normal çiçek oluşturamaması bunun yerine yeşil çiçek olarak adlandırılan şekilsiz küçük yaprakların oluşması, bitki boğum araları kısalması, bitki boyunda kısalmalara ve yapraklarında küçülmelere rastlanması, aşırı yeşillenme ve bitki ucunda cadısüpürgesi denen oluşumlar görülmesidir (Klein, 1977; Salehi ve Izadpanah, 1992; Akhtar ve ark., 2009, Kersting, 1993).

2001 yılında Ege Tarımsal Araştırma Enstitüsü, Menemen'de yapılan bir çalışmada, İzmir'de doğal koşullarda fillodi hastalığı ile önemli oranda enfekte olan ve zarar gören 11 susam çeşidinden 30 bitki seçilmiştir. Tohum örnekleri hastalıklı bitkilerin farklı yerlerinden toplanan kapsüllerden elde edilmiştir. Fillodi ile enfekte olan bitkilerin tohumlarından elde edilen bitkiler, vektörlerden etkilenmemesi için izolasyon kabinlerinde birinci ve ikinci ürün koşullarında 2002 yılında yetiştirilmiştir. Bitki gelişme devresinde periyodik olarak haftada bir yapılan gözlemlerde; seçilen hastalıklı 11 farklı çeşit tohumlardan yetişen bitkilerin fillodi hastalığından ari olduğunu, her iki yetişme sezonunda da bitkilerin normal ve sağliklı olarak geliştiği ve herhangi bir fillodi hastalık belirtisi göstermediği belirlenmiştir. Araştırma sonuçları hastalığın tohumla yayılmadığını ortaya koymuştur (Tan, 2010).

Hindistan'da yapılan bir çalışmada ise fitoplazma DNA'sının, simptomlu susam bitkilerinden ve yaprak pirelerinden $\mathrm{PCR}$ primer çifti P1/P7 ve R16F2n/R16R2 ile tespit edildiğini ortaya çıkmıştır. Bu çalışmada susam bitkisinden örnekler alınıp analiz edilmiş. $\mathrm{Bu}$ analiz sonucunda enfekte olmuş bitkinin simptomsuz dalının sapından hastalık tespit edilmiş, ancak yapraklar, çiçekler, tohum kapsülleri ve kökten tespit edilememiştir. İnfekte olmuş bitkinin simptomlu dalından, kök ve çiçeklerinden fitoplazma tespit edilmiş, fakat yapraklar ve tohum kapsüllerinden tespit edilememiştir (Thangjam ve Vastrad 2018).

Singh ve ark., tarafindan 2018 'de farklı bitki dokuları ile yapılan bir çalışmada susamın 


\section{Susam Bitkisi (Sesamum indicum)'nin Farklı Dokularında Susam Fillodi Hastalığının Araştırılması}

yaprak, gövde ve köklerinde susam fillodi tespiti üzerine çalışma yapmışlar yaptıkları çalışmada her üç bölgede hastalığı belirlemelerine rağmen kökte konsantrasyonun daha az olduğu belirtilmiştir. Bu çalışma ile Adana'nın Karataş, Seyhan, Kozan ve Sarıçam ilçelerinde, Mersin'in Tarsus ilçesinde susam fillodi hastalı̆̆ının simptomunu gösteren susam bitkileri toplanmış ve bu örneklerden seçilen bazı bitkilerin farklı dokularında susam fillodi hastalığının belirlenmesi amaçlanmıştır.

\section{Materyal ve Yöntem}

Çalışmada, Adana'nın Karataş, Seyhan, Kozan ve İmamoğlu ilçelerinde, Mersin'in Tarsus ilçesinde susam yetiştiriciliği yapılan alanlar seçilmiştir. Bu bölgelerde yapılan sörvey sonucu belirlenen susam tarlalarında, yeşil çiçek, küçük yapraklar, internod kısalması, bitki ucunda cadı süpürgesi oluşumu, bodur bitkiler, kapsül içinde çimlenmiş tohumlar ve gövdede yassılaşma gibi hastalık simptomu görülen bitkilerden toplam 39 örnek toplanmıştır.

Susam fillodi ile enfekteli olduğu düşünülen örneklerin ekstraksiyonu için çalışmanın yapılacağ 1 bitki dokularından 200-300 mg alınmış, Li ve ark. (2008)'nın çalışmalarından modifiye edilen CTAB yöntemi kullanılarak ekstraksiyon gerçekleştirilmiş ve $20^{\circ} \mathrm{C}$ 'de PCR yapılıncaya kadar saklanmıştır. PCR analizinin gerçekleştirilmesi için fitoplazma primerleri P1 (Deng ve Hiruki, 1990) ve P7 (Schneider ve ark., 1995) ile nested PCR için R16F2n (Gundersen ve Lee 1996), R16R2 (Lee ve ark., 1998) primerleri kullanılmıştır (Çizelge 1).

Çizelge 1. PCR çalışmalarında kullanılan primer çiftleri

\begin{tabular}{|l|l|}
\hline Primer Ad1 & Primer Dizilimi \\
\hline P1 F; & 5'-AAGAGTTTGATCCTGGCTCAGGATT-3' \\
\hline P7 R; & 5'-CGTCCTTCATCGGCTCTT-3' \\
\hline R16F2 F; & 5'-ACGACTGCTGCTAAGACTGG-3' \\
\hline R16R2 R; & 5'-TGACGGGCGGTGTGTACAAACCCCG-3' \\
\hline
\end{tabular}

PCR çalışmaları $25 \quad \mu \mathrm{L}$ hacimde Bulgular ve Tartışma

gerçekleştirilmiştir.

Adana'nın Karataş, Seyhan, Kozan ve İmamoğlu

Reaksiyon karışım bileşimi; Go tag hot start mix $\left(\right.$ Progema $\left.^{\circledR}\right)$ 12,5 $\mu$ l, Primer F $1 \mu$ l, Primer R 1 $\mu 1$, saf su $8,5 \mu 1$, DNA $2 \mu 1$ olarak alınmıştır.

Çalışmada TA-Technogene PCR cihazı kullanılmıştır. Nested PCR DNA amplifikasyon parametreleri 1 . adımda $94{ }^{\circ} \mathrm{C}$ 'de 2 dakika boyunca başlangıç denatürasyonu 1 döngü, 2 . adımda $94{ }^{\circ} \mathrm{C}^{\prime} \mathrm{de} \quad 30$ saniye boyunca denatürasyon, $50{ }^{\circ} \mathrm{C}^{\prime}$ de 30 saniye replikasyon, $72{ }^{\circ} \mathrm{C}$ 'de 1 dakika uzatma 40 döngü ve 3 . adımda $72{ }^{\circ} \mathrm{C}^{\prime}$ de 10 dakika 1 döngü ile son uzatma yapılmış ve $4{ }^{\circ} \mathrm{C}^{\prime}$ de beklemeye alınacak şekilde programlanmıştır. PCR'yi takiben her bir örnek için $8 \mu \mathrm{l}$ PCR ürün alınarak ve \%1,2'lik agaroz jel elektroforezi ile elde edilen PCR ürünlerinin ethidium bromide boyaması gerçekleştirilmiş ve ultraviole 1ş1k altında görüntülenmiştir.

ilçeleri ve Mersin'in Tarsus ilçesi olarak seçilen çalışma bölgelerinde tesadüfi olarak belirlenen tarlalarda susam bitkileri, Temmuz ve Ekim ayları arasında 4 ay boyunca daha önce belirlenen tarlalarda $20 \mathrm{~cm}$ boyundan itibaren kontrol edilmiş ve hasat yapılıncaya kadar 2 haftada bir tarla ziyaretleri yapılmıştır. İlk haftalarda, bitki boyu kısayken yapılan kontrollerde susam bitkilerinde gözlenen simptomlar; internod kısalması, küçük yapraklar ve kısa boylu bitkiler olmuştur. Bitkiler kısa boylu olduğu dönemdeyken yeşil çiçek, bitki ucunda cadı süpürgesi oluşumu ve kapsül içindeki tohumların çimlenmesi gibi simptomlar bulunmamıştır. Bitkiler olgun döneme geldiğinde özellikle Ağustos ayının 2. Yarısından itibaren hastalık ile enfekteli olduğu düşünülen bitkilerde; bodurluk, bitki ucunda cadısüpürgesi oluşumu, çalılaşma, yeşil çiçek, 


\section{Susam Bitkisi (Sesamum indicum)'nin Farklı Dokularında Susam Fillodi Hastalığının Araştırılması}

kapsül içinde çimlenen tohumlar, gövdede yassılaşma ve küçük yaprak gibi simptomlar gözlemlenmiştir (Şekil 1). Adana'da dört ve Mersin'de bir olmak üzere toplamda beş ilçede ve 15 mahallede çalışma yürütülmüştür (Çizelge
2). Adana ilçeleri ve Tarsus'ta yürütülen çalışmada arazi ziyaretlerinde simptomolojik olarak hasta olduğu düşünülen örneklerle yapılan PCR çalışmaları sonucunda elde edilen

Çizelge 2. Çalışmada toplanılan örneklerin alındığ 1 yerler ve örnek sayısı

\begin{tabular}{|c|c|c|c|}
\hline II & İlçe & Mahalle & Örnek sayısı \\
\hline \multirow{9}{*}{ Adana } & \multicolumn{2}{|l|}{ İmamoğlu } & 7 \\
\hline & \multirow{3}{*}{ Kozan } & Yüksekören & 1 \\
\hline & & Damyeri & 1 \\
\hline & & Pekmezci & 2 \\
\hline & \multirow[t]{2}{*}{ Seyhan } & Karayusuflu & 8 \\
\hline & & Mürseloğlu & 2 \\
\hline & \multirow{3}{*}{ Karataş } & Yeni murat & 6 \\
\hline & & Tabaklar & 3 \\
\hline & & Damlapınar & 1 \\
\hline \multirow{2}{*}{ Mersin } & \multirow{2}{*}{ Tarsus } & Baltal1 & 5 \\
\hline & & Verimli & 3 \\
\hline Toplam & & & 39 \\
\hline
\end{tabular}

PCR ürünleri agar jelde yürütülmüștür. Çalıșma sonucu toplanan örneklerden Kozan'da dört örnekten bir tanesi, Karataş'ta on örnekten altı tanesi ve Tarsus'ta sekiz örnekten üç tanesinin $1.250 \mathrm{bp}$ seviyesinde band oluşturduğu görülmüștür. Seyhan ve İmamoğlu'ndaki örneklerde PCR çalışması sonucu elde edilen ürünlerin jel yürütme çalışmalarında herhangi bir bant gözlenmemiştir (Çizelge 3).

Çizelge 3. PCR çalışması sonucunda enfekteli bulunan örnek sayıları

\begin{tabular}{|l|c|c|}
\hline $\begin{array}{l}\text { Örnek } \\
\text { alınan } \\
\text { ilçeler }\end{array}$ & $\begin{array}{l}\text { Alınan } \\
\text { örnek sayıs1 }\end{array}$ & $\begin{array}{l}\text { PCR pozitif } \\
\text { örnek sayıs1 }\end{array}$ \\
\hline Tarsus & 8 & 3 \\
\hline Kozan & 4 & 1 \\
\hline Karataş & 10 & 6 \\
\hline Seyhan & 10 & 0 \\
\hline İmamoğlu & 7 & 0 \\
\hline Toplam & $\mathbf{3 9}$ & $\mathbf{1 0}$ \\
\hline
\end{tabular}

Fillodi simptomları gösteren bazı örneklerin PCR çalışmalarında negatif sonuç vermesi görülebilecek sonuçlardandır. Susam fillodi hastalığına benzer simptomların farklı hastalıklar tarafından da oluşturulabildiği bilinmektedir. Susam fillodi hastalığının Spiroplasma citri ile birlikte benzer simptomlar oluşturabileceği bildirilmiştir (Başpınar ve ark. 1993). Wilson ve ark. 2001, ise susamlarda fillodi simptomlarına benzer simptomların farklı hastalıklardan kaynaklanabileceğini ve simptomların tek başına hastalığın belirlenmesi için yeterli olmayacağını rapor etmiştir.

Calıșmada fillodi hastalığının susam bitkisinin farklı dokularında belirlenmesinin amacıyla PCR çalışması sonucu pozitif olduğu tespit edilen 10 örnekten üçü (Tarsus'tan bir ve Karataştan iki örnek) çalıșmaya dahil edilmiş, bu amaçla aşağıda maddeler halinde yazılan 10 farklı susam bitkisi dokularında hastalığın belirlenmesi için çalışılmıştır. 


\section{Susam Bitkisi (Sesamum indicum)'nin Farklı Dokularında Susam Fillodi Hastalığının Araştırılması}

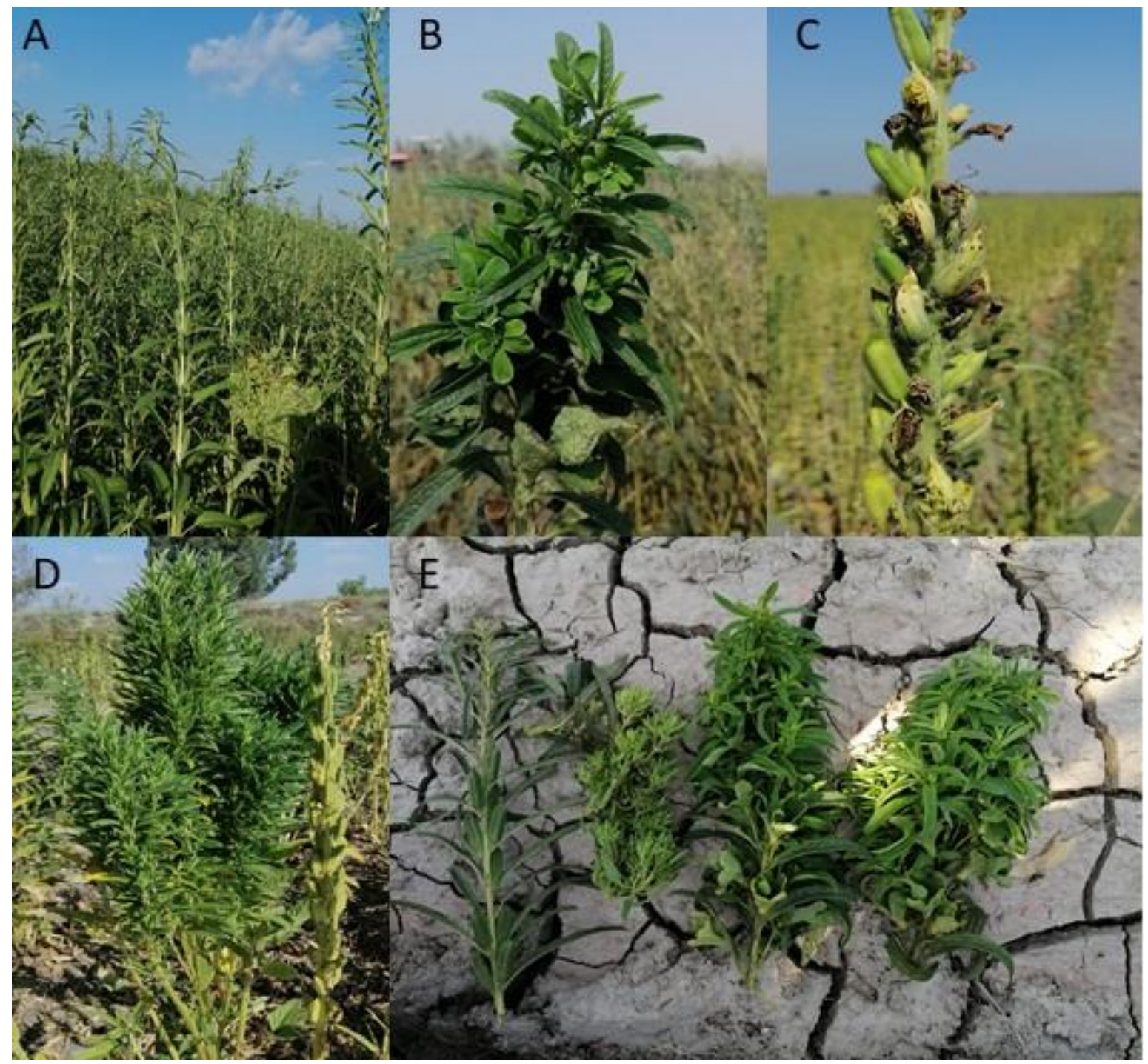

Şekil 1. Adana'nın 4 farklı ilçesinde ve Mersin'in Tarsus ilçesinde yapılan tarla ziyaretlerinde gözlemlenen simptomlar (A. Bitki ucunda cadısüpürgesi oluşumu ve bodurlaşma, B. Bitki ucunda cadısüpürgesi oluşumu ve yeşil çiçek, C. Kapsül içinde tohum çimlenmesi, D. Cadısüpürgesi oluşumu, E. Sıra üzeri ekim yapılmış tarlalarda soldan sağa doğru; sağlıklı bitki, cadısüpürgesi oluşumu, küçük yaprak, yeşil çiçek oluşumu

1. Olgun yeşil çiçek,

2. Küçük yeşil çiçek,

3. Küçük yapraklar

4. Cadı süpürgesi oluşumu,

5. Yaprak sap1,

6. Sürgün kabuğu,

7. Kapsül içinde çimlenmiş tohumlar,

8. Çimlenmiş tohum kapsülleri,

9. Kapsül içinde çimlenmemiş tohumlar

10. Çimlenmemiş tohum kapsülleri

(Şekil 2). 


\section{Susam Bitkisi (Sesamum indicum)'nin Farklı Dokularında Susam Fillodi Hastalığının Araştırılması}

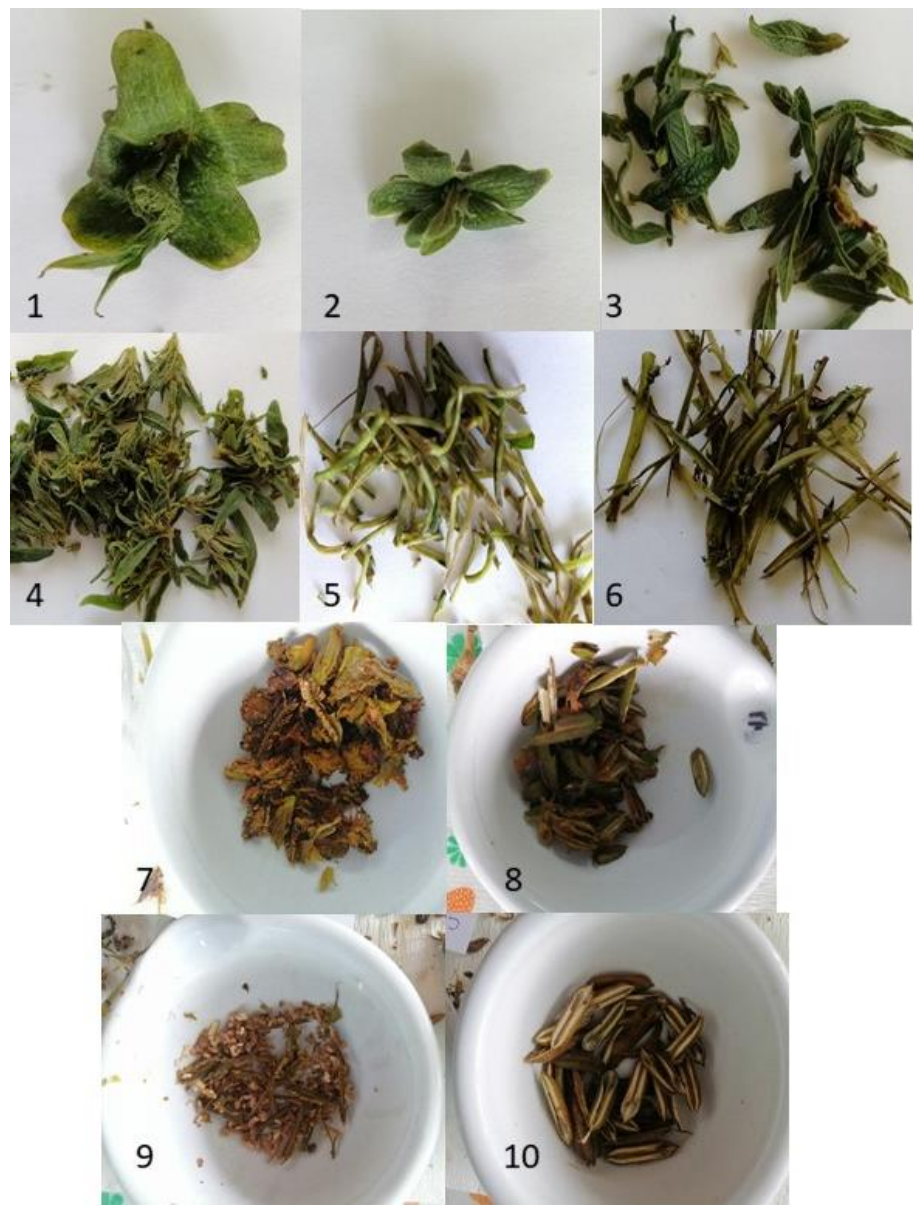

Şekil 2. Simptomlu bitkilerden toplanan çimlenmemiş tohum kapsülleri gibi susam bitkisinin farklı dokularından elde edilen örnekler (1. Olgun yeşil çiçek, 2. Küȩük yeşil çiçek, 3. Küçük yapraklar, 4. Cadı süpürgesi oluşumu, 5. Yaprak sapı, 6. Sürgün kabuğu, 7. Kapsül içindeki çimlenmiş tohumlar, 8. Çimlenmiş tohum kapsülleri, 9. Kapsül içindeki çimlenmemiş tohumlar, 10. Çimlenmemiş tohum kapsülleri)

Önceden enfekteli olduğu belirlenen üç ayrı 3). Bu seviyede bant oluşturan örnekler enfekteli örnekten 10 farklı susam dokuları alınarak tamamı testlenmiştir. Susam fillodi'nin tanılanması için Nested-PCR analizi metodu kullanılmıştır. Hastalığı saptamak için ilk aşamada P1/P7 primer çifti PCR deneylerinde kalıp olarak kullanılmıştır (Deng ve Hiruki 1990; Schneider ve ark., 1995) ardından ikinci aşama PCR analizlerinde R16F2n/R16R2 primer çifti ile (Gundersen ve Lee, 1996) 16S rRNA geninin korunmuş bölgelerinden türetilen kalıplar kullanılmıştır. Elde edilen ürünlerin bandları \%1,2 agaroz jelde yürütülüp ultraviole görüntüleme cihazında görüntülenmiştir. PCR sonuçlarında örneklerin 1.250 bp seviyesinde bant oluşturduğu gözlemlenmiştir (Şekil 2, Şekil olarak değerlendirilmiștir. Susam fillodi simptomu gösteren bitkilerden elde edilen on farklı susam bitkisi dokusunda fillodi hastalığının varlığının belirlenmesi amacıyla yapılan çalışmada tüm örneklerden pozitif sonuç elde edilmiştir.

\section{Sonuç ve Öneriler}

Kozan ilçesi susam yetiştiriciliği yapılan alanlarda diğer alanlardan farklı üretim yapıldı görülmüştür. Diğer ilçelere göre Kozan'da tarlanın toprağının tam hazırlanmadığı, pullukla sürülüp direkt ekim yapıldığı, ekimin mibzerle değil elle atılarak gerçekleştirildiği, sulama ve gübrelemenin olmadığı, çapalama gibi bir çok kültürel işlemin gerçekleştirilmediği 


\section{Susam Bitkisi (Sesamum indicum)'nin Farklı Dokularında Susam Fillodi Hastalığının Araştırılması}

görülmüştür. Diğer ilçelerde ise kültürel işlemlerin tam yapıldı $\breve{g} 1$ ve Kozan'daki susam veriminin $30-70 \mathrm{~kg} / \mathrm{da}$, diğer ilçelerdeki verimin $130-240 \mathrm{~kg} / \mathrm{da}$ arasında olduğu buna bağlı olarak yaklaşık iki kat verim alındığı tespit edilmiştir.

Susam bitkisinin farklı dokularında susam fillodi hastalığının olup olmadığı üzerine yapılan çalışmada susam fillodi'nin susam bitkisinin 10 farklı dokusundan elde edilen örneklerin tümünde gerçekleştirilen PCR çalışmalarında pozitif sonuçlar elde edilmiştir. Hastalığın çalışılan her bitki dokusundan rahatlıkla tespit edilebileceği belirlenmiştir. Daha önce yapılan çalışmalarda hastalığın aşı, küsküt ve vektör ile taşınabildiği fakat tohum çalışmalarında susamda tohum ile taşınmanın olmadığ 1 farklı araştırıcılar tarafindan (Tan, 2010, Akhtar ve ark. 2009) belirlenmiş, bu çalışmada ise
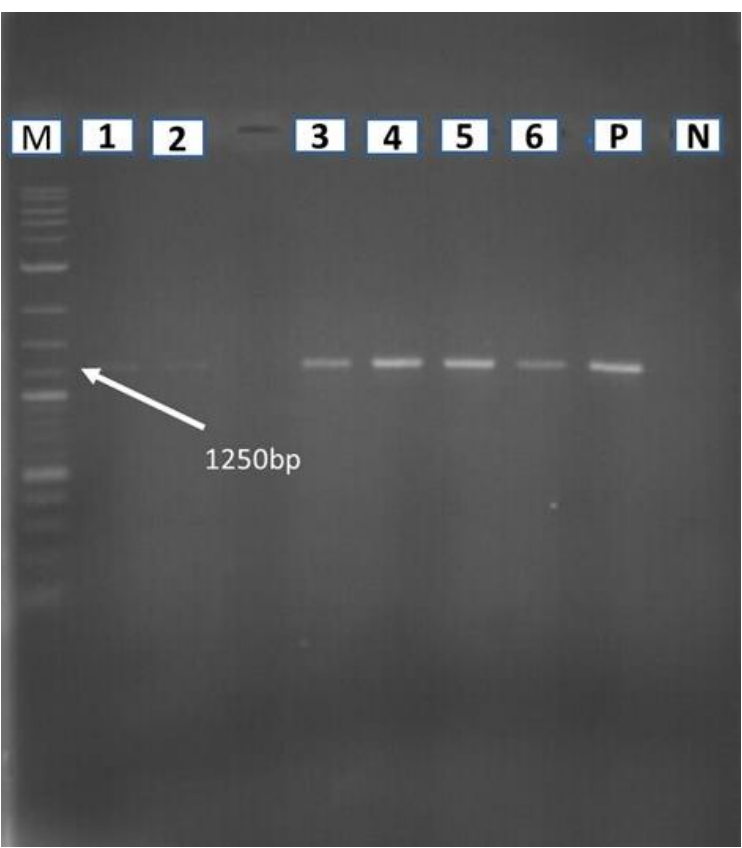

Şekil 3. \%1,2'lik agaroz jelde marker (M; 2-Log DNA Ladder (0.1-10.0 kb)), örnekler (1, 2, 3, 4, $5,6)$, pozitif kontrol (P) ve negatif kontrol (N)'ün UV' de görüntüsü bitkinin farklı bir çok dokusunda hastalığın belirlenmesinin yanında susam tohumunda susam filodi hastalığı saptanmasına rağmen bu infekteli olarak tespit edilen tohumların kurutulup, tekrar ekilerek bu tohumlardan gelişen vejetatif aksamda hastalığın tespiti gerekmektedir. Fitoplazmalar uzun yillara boyunca tohumla taşınması konusunda bir yayın bulunmazken son yillarda tohumla taşınma ile ilgili raporlar yayınlanmaya başlanmıştır. Kumari ve ark., 2019 yayınlarında fitoplazmaların leafhopper vektörleri, bitki çoğaltma materyali yanında tohumla da taşınabildiğini bildirmişlerdir. Satta ve ark., 2019 ise fitoplazmaların birçok otsu ve odunsu bitkilerde tohumla taşındığının saptandığını bildirmișlerdir. $\quad \mathrm{Bu}$ çalıșmanın devamında hastalık belirlenen tohumların ekimi yapılarak tohumdan elde edilen susam bitkilerinde susam fillodi hastalığının varlığı araştırılacaktır

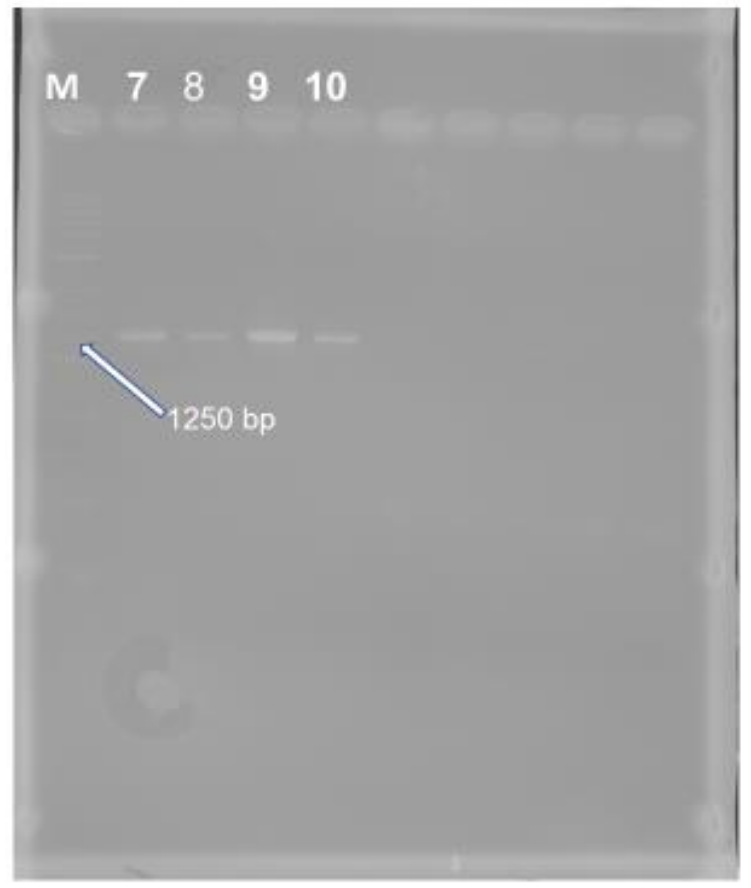

Şekil 4. \%1,2'lik agaroz jelde marker (M; 2-Log DNA Ladder (0.1-10.0 kb)), örnekler (7, 8, 9, 10)' in UV' de görüntüsü 


\section{Susam Bitkisi (Sesamum indicum)'nin Farklı Dokularında Susam Fillodi Hastalığının Araştırılması}

\section{Kaynaklar}

Akhtar, K. P., Sarwar, G., Dickson, M., Ahmad, M., Ahsanul Haq, M., Hameed and Javeed Iqbal, M., 2009. Sesame phyllody disease: Its symptomatology, etiology and transmission in Pakistan. Turkish J. Agriculture and Forestry. doi:10.3906/tar0901-23.

Arslan H., Hatipoğlu, H. ve Karakuş, M., 2014. Şanlıurfa Yöresinde Tarımı Yapılan Susam Genotiplerinden Seçilen Bazı Hatların İkinci Ürün Koşullarında Verim ve Verim Unsurlarının Belirlenmesi Turk J. Agric. Res. (2014) 1: 109-116 TÜTAD ISSN: 2148-2306.

Baspinar H, Korkmaz S, Önelge N, Çınar A, Uygun N and Kersting U., 1993. Studies on Citrus Stubborn Disease pathogen and Sesame phyllody MLO and their assocated leafhopper vectors in sesame. The Journal of Turkish Phytopathology, (1): 1-8.

Deng S. J. ve Hiruki C., 1990. enhanced detection of a plant pathogenic mycoplasma-like organism by polymerase chain reaction proc jpn acad 66b 140-144.

FAO, 2018. ISPM 27. Annex 12. Phytoplasmas. IPPC, FAO, Rome (IT).

Gundersen, D. E., \& Lee, I.-M., 1996. Ultrasensitive detection of phytoplasmas by nested-PCR assays using two universal primers. Phytopathologia Mediterranea, $35,144-151$.

Kersting U., 1993. Symptomatology, etiology and transmission of Sesame phyllody in Turkey. The Journal of Turkish Phytopathology 22: 47-54.

Klein M., 1977. Sesame phyllody in Israel. Phytopathologische Zeitschrift 88: 165171.

Kumari, S., Nagendran, K., Rai, A.B., Singh, B., Rao, G.P., Bertaccini, A., 2019. Global Status of Phytoplasma Diseases in Vegetable Crops. Frontiers in Microbiology, 10:1349. doi: 10.3389/fmicb.2019.01349.

Lee, I.M.; Gundersen-Rindal, D.E.; Davis, R.E.; Bartoszic, I.M. 1998. Revised classification scheme of phytoplasma based on RFLP analyses of $16 \mathrm{~S}$ rDNA and ribosomal protein gene sequences. International Journal of Systematic Bacteriology 48: 1153-1169.

Li, R., Mock, R., Huang, Q., Abad, J., Hartung, J., Kinard, G., 2008. A Reliable And İn Expensive Method Of Nucleic Acid Extraction For The Pcr-Based Detection Of Diverse Plant Pathogens. Journal of Virological Methods 154 (1-2): 48-55.

Salehi M., Izadpanah K., 1992. Etiology and transmission of Sesame phyllody in Iran. Journal of Phytopathology 135: 37-47.

Satta E., Paltrinieri S., Bertaccini A., 2019. Phytoplasma Transmission by Seed. In: Bertaccini A., Weintraub P., Rao G., Mori N. (eds) Phytoplasmas: Plant Pathogenic Bacteria - II. Springer, Singapore. https://doi.org/10.1007/978-981-132832-9_6

Schneider, R., Massow, M., Lisowsky, Weiss H., 1995. Different respiratory-defective phenotypes of Neurospora crassa and Saccharomyces

cerevisiae after inactivation of the gene encoding the mitochondrial acyl carrier protein. Curr Genet 29, 10-17. https://doi.org/10.1007/BF00313188

Singh V., Kumar S., Lakhanpau S., 2018. Differential distribution of phytoplasma during phyllody progression in sesame (Sesamum indicum L.) under field conditions - An important consideration for effective sampling of diseased tissue. Crop protection 110(2018) 288-294.

Tan A. S., 2010. Screening phyllody infected sesame varieties and seed transmission of phyllody under natural conditions in turkey. J Ayub Agric Res Inst 20(1):2633.

Thangjam, R., \& Vastrad, A., 2018. Molecular detection of phytoplasma from phyllody infected sesame and its vector orosius albicinctus distant. Indian journal of entomology, 80, 124-126.

Wilson, D., Blanche, K.R. \& Gibb, K.S., 2001. Phytoplasmas and disease symptoms of crops and weeds in the semi-arid tropics of the Northern Territory, Australia. Australasian Plant Pathology 30, 159-163. 